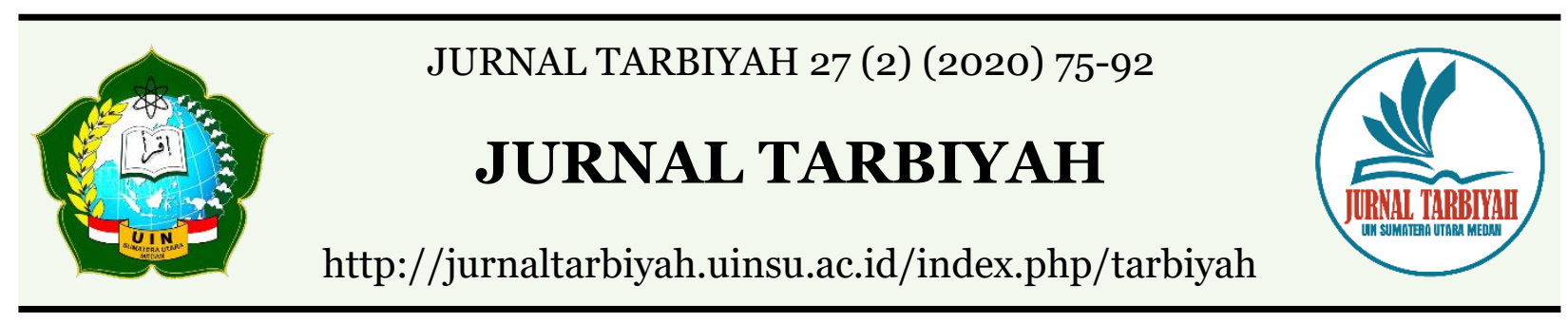

\title{
INNOVATION OF MANAJEMENT IN IMPROVING ISLAMIC EDUCATION LEARNING QUALITY AT MAN 2 MODEL MEDAN
}

\author{
Fachruddin Azmi' ${ }^{1}$,Syafaruddin², Khairuddin3 \\ 1,2,3 Universitas Islam Negeri Sumatera Utara Medan, Indonesia \\ Email: fachruddinazmi@uinsu.ac.id,syafaruddinsiahaan@uinsu.ac.id, \\ khairuddinld@uinsu.ac.id
}

DOI : 10.30829/tar.v27i2.774

Accepted: September 24th, 2020. Approved: December 25th, 2020. Published: December 31th, 2020

\begin{abstract}
This study is aimed to determine management innovation as an effort to improve the quality of learning Islamic religious education at Madrasah Aliyah Negeri (MAN) 2 Medan Model. The formulation of this study is focused on examining the aspects of planning, implementation, monitoring and evaluation implemented by the madrasah as an effort to improve the quality of Islamic Education learning. A qualitative was used as research approach. The data was obtained through interviews, observation, and documentation. Data analysis was analyzed through data reduction, data presentation, and data verification. The results of this study indicate that management innovation as an effort to improve the quality of Islamic education learning in MAN 2 Model Medan was carried out well. This is indicated by the ongoing learning activities in accordance with 4 aspects of the management function, they are: (1) planning which was carried out through annual meetings (deliberations) in determining strategic programs and activities and conceptualizing through lesson plan accompanied by varied media and methods; (2) implementation that is implemented based on lesson plan, added with extracurricular activities that were integrated with Islamic Education learning in the classroom, (3) internal supervision by the principal of madrasah to subordinates, added to providing guidance and counseling, and equipped with security by security staffs, and (4) learning evaluation was carried out by implementing routine and programmed tests, where evaluation is not only based on numbers, it coupled with an evaluation of students' religious experience in their respective environments.
\end{abstract}

Keywords: Innovation, Management, Islamic Education Learning. 


\section{INTRODUCTION}

The quality of education in certain educational units can be indicated as excellent an increase is existed in the aspects of input, process, and output, including at senior high school (and equivalent level) institutions such as Madrasah Aliyah (in Bahasa Indonesia called as: MA) (Rohiat, 2001). The input aspect that is available in adequate levels, completed with an effective and efficient process, as well as output that is able to answer the needs of the community, are necessities for the principal as the leader through various strategies and innovative efforts in realizing an increasing the quality of education institution ( Alba, 2011; Sujoko, 2017).

In order to fulfill the efforts to improve quality, certainly achieved based on relations and equality (link and match). This is inseparable from the management aspect, which is embodied in the elements of institutional management and learning (Suryapermana, 2016; Sulaeman, 2018; Asmara \& Nindianti, 2019). The quality of learning and institutional management conceptualized in the curriculum, naturally, cannot guarantee the quality of the conceptualized program. For that, a good strategy and management is needed, supported by qualified, competent and dedicative resources in producing a conducive ambiance in education units (Fadhli, 2017). In this context, advanced planning is needed (Kuntoro, 2019; Kurniawan, 2017; Mubarak, 2015) by giving attention to aspects of conditions, corporate culture, strategies, steps, and types of assessment criteria and indicators to be determined (Nurcholis, 2003).

Education planning can actually be well conceptualized and measured by education stakeholders. On the other hand, education experts are unable to deny that there are striking differences with the reality on real implementation, where education experiences complex problems, covering philosophical aspects, vision, mission, ideas, programs, management, human resources, education environment, financing, exemplary, trust, community participation and quality. In addition, the mentality of institutional leaders and "involved parties" of educational units in facing the dynamics that grow in society and the socio-cultural demands of the surrounding area are also required (Muchsin \& Wahid, 2009; Nugroho, 2016).

Further, Madrasah is an institution under the auspices and guidance of the Ministry of Religion. Likewise, madrasas are actually community-based institution. The number of madrasas currently is 70,414 . Among the total number, only $8.63 \%$ are managed by the Ministry of Religion, namely Madrasah Aliyah Negeri (State Madrasah Aliyah, senior high school level), while private madrasah managed by the community 
(foundations) are 91.37\% (Directorate of Madrasah, 2014). This fact means that overall madrasas do not belong to the government, but belong to the community (in larger numbers). Therefore, good management is needed in managing these private madrasah.

In the meantime, the role of madrasas as a sub-system in national education is a real contribution made by Muslims to the development of superior human resources (Haningsih, 2008; Rochmawati, 2012; Rahim, 2014). In particular, by using quantitative calculations, in Medan there are 4 State Madrasah Aliyah whose existence ancontribution have been measured. Besides private Madrasah Aliyah, Madrasah Tsanawiyah (junior high school level, known as MTs) both public and private, as well as Madrasah Ibtidaiyah (elementary level, known as MI) and Raudhatul Athfal (kindergarten level, known as RA), are quite numerous. According to the data from the Department of Religion of Medan, there are 18 state madrasas, consisting of 12 MIN, 3 MTs, and 3 MAN.

However, MAN 2 Medan Model tries to make a breakthrough to make a change (innovation) in education, including innovation in learning management to achieve their goals. The Islamic Madrasah Aliyah educational institution refers to the Ministry of National Education and Culture and is integrated with the Ministry of Religion's curriculum in its curriculum reference which is part of the Islamic Religious Education family (Alquran-Hadith, Fiqh-Ushul Fiqh, Islamic Cultural History, Akidah Akhlak and Arabic).

Based on these descriptions, it is important to study and analyze in depth the innovations that have implemented made by MAN 2 Model Medan to improve the quality of graduates. Thus, researchers are interested in conducting research with the title: "innovation of manajement in improving Islamic Education learning quality at MAN 2 Model Medan."

\section{METHOD}

This research is focused on the analysis of Islamic Education learning management innovation. This scientific study is aimed to describe and then analyze the management theory and learning innovation in improving the quality of Islamic Education learning in MAN 2 Medan Model. Therefore, the use of a qualitative approach is appropriate to obtain data and reveal empirical facts in this research (field research). The research data was collected using interview, observation, and documentation study techniques. Then the data were analyzed continuously through data reduction techniques, data presentation, 
and then finally the conclusion drawn. Moroever, for the validity of the data, crosschecking or triangulation techniques (methods and sources) were used.

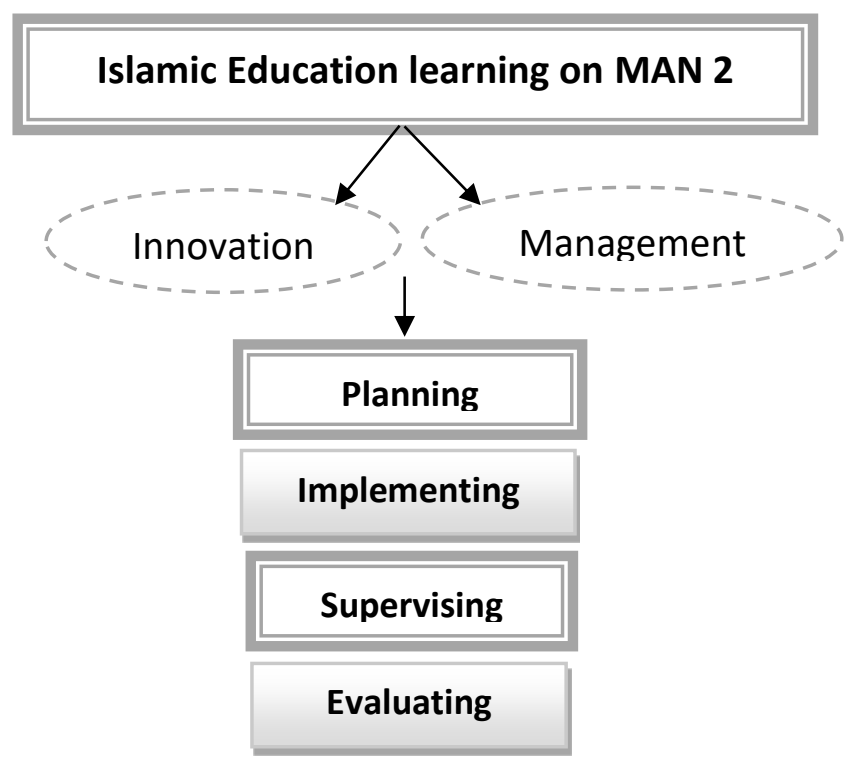

Flowchart 1. Research Flow

\section{RESULTS AND DISCUSSION}

\section{Innovation of Learning Planning in Improving the Quality of Islamic} Education at Madrasah Aliyah Negeri 2 Model Medan

Innovations is generally defined by experts to mean everything that is new or renewed. Other experts also stated that innovation also those who state discoveries, because new ones are the results of discoveries (Syafaruddin, et.al, 2012). The word invention is also often used to translate the English word discovery and invention. There is also a link between the notions of innovation and modernization, in case they both discuss reform (Sa'ud, 2011). Thus, borrowing the term of Syafaruddin (2012), innovation is introducing new ideas or new items, new services and new ways that are more beneficial to human life. Innovation is also often interpreted as modernization or renewal (Napitupulu, 2018). In the context of this research, the innovation is the various modernizations and reforms implemented by Madrasah Aliyah Negeri 2 Model Medan.

For more details regarding the innovation in learning planning at Madrasah Aliyah Negeri 2 Model Medan, it can be seen on the following scheme: 


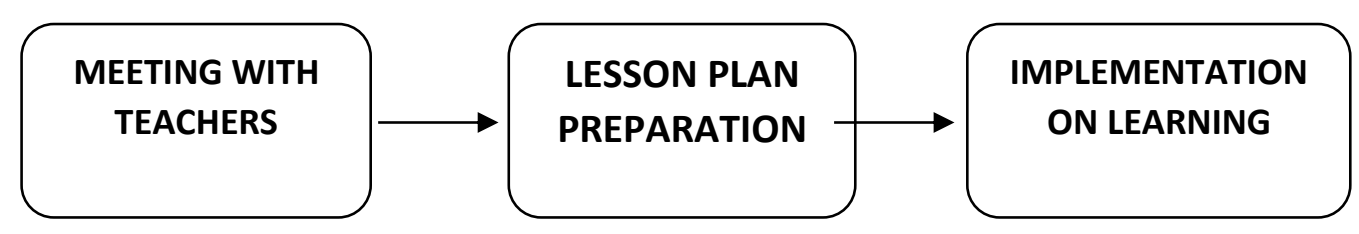

\section{Scheme 2: Innovation of Learning Planning Chart at Madrasah Aliyah Negeri 2 Model Medan}

Innovation is the one of important parts in the world of education. Through innovation, various policies have be formulated by discovering new things and adapting to the times (Priatmoko, 2018). Otherwise, before moving to action, according to management principles, the first step that should be taken is the planning process.

In classroom management innovations in history subject, the task of educators are vary, they should be facilitators, mediators, and moderators in the teaching and learning process (Anam, 2016). It is hoped that the atmosphere or learning environment will no longer be suppressing students, forcing students and burdening students, but stimulating students with something interesting, provoking students with a fun challenge, motivating students to be more advanced, and stimulating students with fun activities (Ramdhani, 2014; Syaifudin, 2016; Santoso \& oktafien, 2018). Certain conditions and classroom climates that are innovative will encourage the realization of a more effective history learning process: fun, educate, strengthen, and live and give freedom (Asmuni, 2015).

Planning is dependent and limited to one understanding. This is due to the various meanings of planning in various fields of science. Various meanings of planning depend on the point of view and background that influences a person (Dolong, 2016). Planning is a disciplined effort to make important decisions and actions that shape and guide how to become an organization or other entity, what the organization acts and why the organization act things (Bryson, 2008). Meanwhile, according to Sarbini \& Lina (2011), planning is an attempt to find out who is responsible for certain activities to achieve common goals. These activities are reflected in a thorough and comprehensive planning.

Planning plays an important role, especially in the scope of education in case it determines and simultaneously provides direction to the goals to be achieved (Dolong, 2016). With careful planning and well management, innovation will bring an influence on the achievement of goals. Likewise, according to Syafaruddin (2017), education planning 
is the process of setting goals in educational organizations, or determining something that will be implemented in the future to achieve organizational goals and objectives effectively and efficiently.

In the field of education, the implementation of plan is manifested in the Lesson Plan (in Bahasa Indonesia known as RPP, Rencana Proses Pembelajaran). The need for lesson plann is intended so that learning improvements can be achieved (Uno, 2011). Efforts to improve learning are carried out with the following assumptions: (1) to improve the quality of learning, it is necessary to begin with learning planning which is realized by the existence of learning designs; (2) to design a study, it is necessary to use a systems approach; (3) learning design planning refers to how a person learns; (4) to plan a learning design directed to individual students; (5) learning that is implemented will lead to the achievement of learning objectives, in this case there will be direct learning objectives, and accompanying objectives of learning; (6) the final goal of planning the learning design is the ease with which students learn; (7) learning planning shoul involve all learning variables; and (8) the essence of the learning design created is the determination of the optimal learning method to achieve predetermined goals.

According to Saefuddin \& Syamsuddin (2007), there are several important elements in educational planning. These elements are: (1) the use of rational and systematic analysis in educational planning, which involves methodology in planning; (2) the process of education building and development, which means education planning should be implemented in the framework of educational reform; and (3) the principle of effectiveness and efficiency, which means that in educational planning, economic thinking is very prominent.

From those definitions, it can be concluded that the innovation of learning planning at Madrasah Aliyah Negeri 2 Medan is based on a meeting held annually to plan strategic activities for various programs to be implemented. Furthermore, the planning innovation is implemented in the Lesson Plan (RPP) which should be applied by every teacher of the Islamic Religious Education subject. Then the lesson plan is applied in learning in each class using various media and methods.

\section{Innovations of Learning Implementation in Improving the Quality of Islamic Education at Madrasah Aliyah Negeri 2 Model Medan}

The innovation of the implementation of learning in improving the quality of Islamic education at Madrasah Aliyah Negeri 2 Model Medan is based on the Lesson Plans 
(RPP) that have been compiled by each teacher and implemented inside and outside the classroom in the form of learning. Innovation in the implementation of learning in the classroom is applied by using various methods and varied learning strategies. The innovation in implementing learning outside the classroom is carried out in the form of compulsory programs (full day school) and various other extracurricular activities.

A description of the innovative implementation of learning at Madrasah Aliyah Negeri 2 Model Medan can be summarized in the following chart:

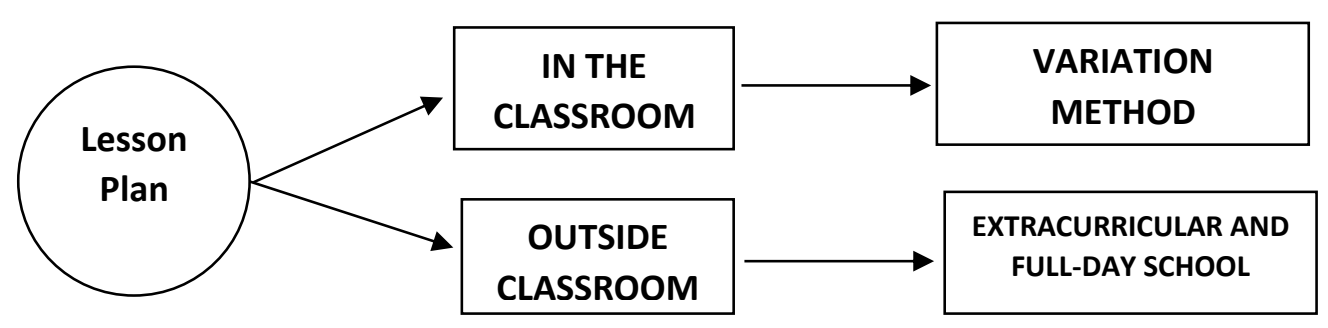

\section{Scheme 3: Innovation of the Learning Implementation Chart at Madrasah Aliyah Negeri 2 Medan Model}

The regulation implementation is a series of activities and decisions that facilitate policy statements in the formulation of organizational practices (Alfiansyah, et.al., 2020). Furthermore, implementation of regulation requires a number of decisions and actions by the principal (Assingkily \& Mesiono, 2019). There are four important factors in implementing policies, they are: communication, sources, dispositions or attitudes and bureaucratic structures (Syafaruddin \& Erawadi (ed.), 2020). Therefore, to implement the policy, there are two possible steps: directly implementing it in the form of programs, or through derivative policies of the public policy.

Based on the those considerations, it can be concluded that the regulation implementation process does not only concern the behavior of administrative parties which are responsible for implementing the program and engendering adherence to the target group, but also concerning the network of political, economic and social forces which can directly or indirectly influence the behavior of all parties involved. Besides, in the end it affects the impacts, both expected (intended) and unexpected (unintended/negative effects) (Rusdiana, 2015).

Furthermore, in the concept and meaning of implementation, Lineberry in Rusdiana also stated that the implementation process has the following elements: (1) the 
formation of new organizational units and executors; (2) the elaboration of objectives into sharing rules of implementation (standard operating procedures/SOP); (3) coordination of various sources and expenditures in target groups, division of tasks within and among agencies and implementing agencies; and (4) allocation of resources to achieve objectives. These components implementation process are directly related to the factors as analyzed by Mazmanian and Sabatier. They explained that the process of implementing public policies should be considered from the its strict control and coordination to achieve the results.

In addition, good learning implementation is learning based on strategic plans that have been made before the implementation of learning. In the classroom, the role of the Lesson Plan (RPP) is very significant. Thus, before entering the classroom, each teacher is required to prepare lesson plan. In case, the lesson plans that have been developed actually contain elements that significantly affect learning such as media, methods and assessment techniques used during learning process.

When those elements are applied, the learning objectives will be achieved as expected. However, in reality in the field, we see that there are still many teachers who think that the lesson plans they compile are only for fulfilling administrative duties, so that in preparing the lesson plans, the teaching tools bring no value at all in learning. Apart from the lesson plans, there is also a syllabus that has very important role. The

syllabus can be simply defined as an outline of the summary or main material that will be carried out in the learning process.

By those recognitions, it can be concluded that innovation in the implementation of learning in improving the quality of Islamic education at Madrasah Aliyah Negeri 2 Model Medan is based on the Lesson Plan (RPP) that has been compiled by each teacher and implemented inside and outside the classroom in the form of learning. Innovation in the implementation of learning in the classroom is applied by using various methods and learning strategies. The innovation in implementing learning outside the classroom is carried out in the form of compulsory programs (full day school) and various other extracurricular activities.

\section{Innovations of Learning Supervision in Improving the Quality of Islamic} Education at Madrasah Aliyah Negeri 2 Model Medan

The supervision efforts being implemented was making coordination with the deputy head of the madrasah in the field of curriculum then proceed with the 
appointment to the Islamic Religious Education (PAI) teachers who teach in each class. From the teacher then the supervision is given to the guidance and counseling teacher. At this stage the guidance and counseling teachers do not only act as a monitor for student behavior, but also take a role in developing the potential, interests and talents of each student. Moreover, at home, it is the role of each parent in supervising student learning. So that supervision of learning is not only carried out when students are in school, but also supervision of learning is implemented when students are at their homes.

In field of management science, the position of supervision is part of the supervisory function carried out by managers in each organization (Syafaruddin, et.al., 2020). Therefore, the concepts, functions, and supervision techniques need to be understood by managers and office leaders who manage education, both the head of the Dducation and Culture Department, the principal, the vice principal of the school, the supervisors and the teachers.

Supervision is observing or guiding and stimulating activities carried out by other person with the intention of making improvements. Monitoring is necessary when looking at the extent to which these results have been achieved. Supervision is a basic process that is essential, complex and extensive on an organization. The process consists of three stages: (1) establishment of implementation standards; (2) measurement of work implementation compared to standards; and (3) determination of the gap (deviation) between implementation and standards and plans (Fattah, 2001).

Supervision in educational organizations is directed at the implementation of school programs as a whole, whose aim is to improve the quality of learning in certain institutions. In this context, the assessment of educational institutions is intended as: (1) effectiveness and efficiency of the implementation of teacher duties; (2) use of learning facilities; (3) kinds of treatment of students by teachers; (4) student learning outcomes; (5) changes in attitudes and maturity of students; and (6) employee work programs and all elements that are related to the process of achieving school goals (Pidarta, 2009).

Based on the results of the investigawtion, it can be assumed that in terms of supervising students at Madrasah Aliyah Negeri 2 Model Medan involves the role of guidance and counseling teachers as personnel who are authorized not only to handle students who have problems but also to guide the development of students' talents and interests, in order to be optimized to have a bright future.

To further clarify the innovation of learning supervision at Madrasah Aliyah Negeri 2 Model Medan, it can be seen in the chart below: 


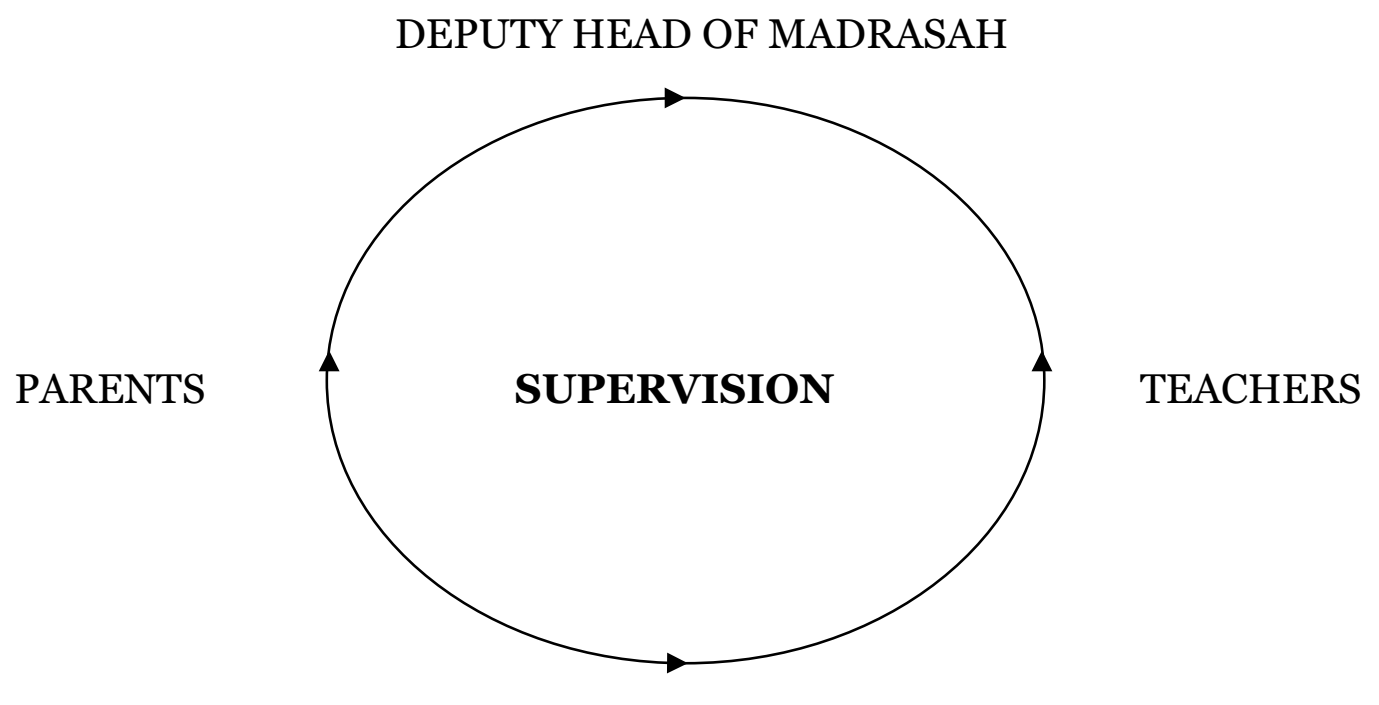

GUIDANCE AND COUNSELING TEACHERS

\section{Scheme 4: Innovation of Learning Supervision Chart at Madrasah Aliyah Negeri 2 Model Medan}

Supervision in educational organizations is necessary when considering the extent to which these results have been achieved. Supervision is a basic process which is essentially still necessary no matter how complex and broad an organization. The basic process consists of the following three stages: (1) Eestablishment of implementation standards; (2) measurement of work implementation compared to standards; (3) determination of the gap (deviation) between implementation with standards and plans (Fattah, 2001).

Based on these stages, the learning supervision innovation in Madrasah Aliyah Negeri 2 Model Medan is carried out in accordance with the supervision stages as conveyed by Nanang Fattah. Supervision is carried out for the first time by setting implementation standards. This step has been determined at the beginning of the semester meeting with the entire teacher councils. The meeting discussed technical matters that would advance madrasah with special programs. Then, the second step applied in terms of supervising learning is by measuring the implementation of work compared to predetermined standards.

Specifically to help measure this second step, Madrasah Aliyah Negeri 2 Model Medan has its own Deputy Head of Madrasah (Wakil Kepala Madrasah, WKM) whose functions as a person that has the authority to assess teacher performance which is then known as WKM Teacher Performance Assessment. This duty what will then supervise 
teacher performance, who monitor directly in the classroom how the teacher implements learning, whether it is in accordance with the lesson plan that has been prepared beforehand, or not. Assessment of teacher performance is carried out periodically, that is, during every semester each teacher be assessed, regardless of whether the teacher is a civil servant teacher or an honorary teacher.

Meanwhile, the fourth step of learning supervision is to determine the gap (deviation) between the implementation and planning that has been created previously. Each teacher gets the results of the performance appraisal from the deputy head of the madrasah in charge of their works. Thus, the concept of learning supervision run effectively. Beside, the purpose of the supervision is not only applied to students but also to teachers. Thus, the learning objectives as originally planned will be maximally realized.

By those explanations, it can be concluded that the innovation of learning supervision in improving the quality of Islamic education at Madrasah Aliyah Negeri 2 Model Medan is making coordination with the deputy head of the madrasah in the field of curriculum then continued with the delegation to the Islamic Religious Education (PAI) teachers who teach in each class. From the teacher then the supervision is given to the guidance and counseling teachers. At this stage, the guidance and counseling teacher do not only act as a monitor for student behavior, but also plays role in developing the potential, interests and talents of each student. As for at home, it is the role of each parent in supervising student learning. So that supervision of learning is not only carried out when students are in school, but also supervision of learning is carried out when students are at their homes.

\section{Innovation of Learning Evaluation in Improving the Quality of Islamic} Education at Madrasah Aliyah Negeri 2 Model Medan

Evaluation is an effort to determine the level of implementation of a policy respectively by understanding the effectiveness of each component (Arikunto \& Jabar, 2014). In short, Mutrofin (2010) explained a definition of evaluation as a systematic activity carried out to help the institutions to consider and increase the value of a program or activity. Furthermore, according to Purwanto \& Suparman (1999), evaluation is the process of applying scientific procedures to collect valid and reliable information to make decisions about education and training programs.

Based on this definition, four main elements are conceptualized in evaluation, they are: (1) evaluation regularly applies a scientific method in the form of scientific 
measurement through the use of statistics or other related disciplines; (2) evaluation activities always try to obtain information that is truly valid and reliable by using instruments in the form of tests, questionnaires, interview guides, observation guidelines and others; (3) the results of the evaluation are information that can be useful for decision makers; and (4) evaluation activities are always directed to an object in a learning or training education system.

Based on the definitions above, it can be concluded that the meaning of evaluation contains three aspects which become a point of emphasis, they are: (1) evaluation activity is a systematic process; (2) in evaluation process, various information or data are needed concerning the object being evaluated; and (3) each evaluation process cannot be separated from the objectives to be achieved (Purwanto, 2001).

Innovation of learning evaluation in Madrasah Aliyah Negeri 2 Model Medan can be seen in the following chart:

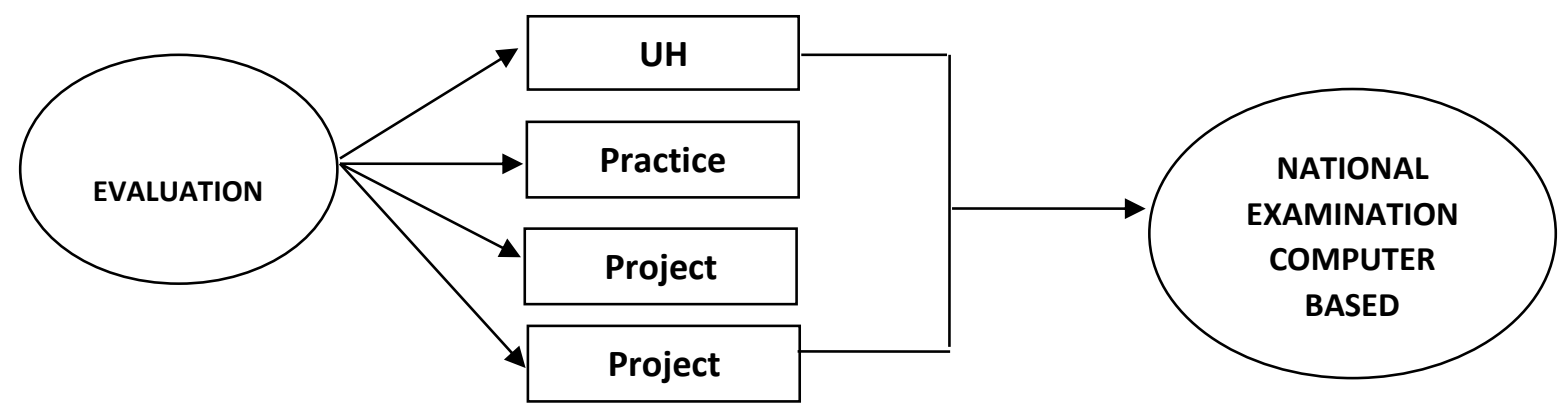

\section{Scheme 5: Innovation of Learning Evaluation Chart at Madrasah Aliyah Negeri 2 Model Medan}

Evaluation as part of management and learning innovation efforts includes various aspects and dimensions of learning implemented in MAN 2 Model Medan. The aspects being evaluated are; (1) results within a certain period of time, (2) costs to achieve results and comparison with the available budget, (3) personnel and services required, (4) madrasah facilities and infrastructure used to achieve certain results, and utilization of these facilities, and (5) effectiveness of the mechanisms and SOP that have been determined.

Based on the evaluation concept above, the learning evaluation innovation carried out by Madrasah Aliyah Negeri 2 Model Medan is in accordance with the evaluation elements mentioned above. It is started from the results achieved within a certain time. The results assessed are teacher performance and student scores which are continuously 
assessed by each subject teacher. Assessment of students is carried out at least on daily tests, mid-semester and end-of-semester examination. As for the teacher performance evaluation, it is carried out once in every semester.

The second aspect in the evaluation as in the theory explained above is the context of cost, where in the context of evaluating learning costs are not counted. In case, it is not correlated with learning, likewise with the necessary infrastructure and manpower. However, the last element, the effectiveness and working mechanism that has been determined, has a significant relationship.

Through learning evaluation activities, it will be found how the suitability of time allocation and student learning outcomes, whether all basic competencies and learning indicators can be completed within a predetermined time or not (Ardhi, 2015). If appropriate, learning can be assumed to be effective, but if not, learning cannot be assumed to be effective. Likewise with the Minimum Completeness Criteria (Kriteria Kelulusan Maksimum, KKM), if the majority of students are able to exceed the predetermined completeness value, it can be measured that the learning is successful, and vice versa.

From the definition above, it can be concluded that learning evaluation innovations in improving the quality of Islamic education at Madrasah Aliyah Negeri 2 Model Medan are carried out by implementing regular and scheduled tests, not only in numbers, but also in the form of evaluating students' religious practice in their respective environments.

\section{CONCLUSION}

Inovasi perencanaan pembelajaran di Madrasah Aliyah Negeri 2 Model Medan dilakukan berdasarkan rapat yang diselenggarakan setiap tahunan untuk merencanakan kegiatan strategis berbagai program yang akan dilaksanakan. Selanjutnya inovasi perencanaan tersebut diimplementasikan pada Rencana Pelaksanaan Pembelajaran (RPP) yang wajib dikerjakan oleh setiap guru mata Pelajaran Pendidikan Agama Islam. Kemudian RPP tersebut diterapkan dalam pembelajaran di kelas masing-masing dengan menggunakan media dan metode yang variatif.

Learning planning innovation at Madrasah Aliyah Negeri 2 Model Medan is carried out based on a meeting held annually to plan strategic activities for various programs to be implemented. Furthermore, the planning innovation is implemented in the Lesson Plan (RPP) which should be achieved by every teacher of the Islamic Religious 
Education subject. Then the lesson plan is applied in learning in each class by using various media and methods.

As for the innovation in the implementation of learning implemented in Madrasah Aliyah Negeri 2 Model Medan, in general, it is guided by the Lesoon Plan (RPP) that has been prepared by each teacher. In addition to teaching and learning activities in the classroom, there are also learning activities that are integrated with extracurricular activities or programs. Learning the Alquran and Hadith, for example, apart from being carried out in the classroom, there are also extracurricular activities in the form of Tahfiz Alquran, Fahmil Alquran, and the development of recitations of the Alquran. Likewise, Fiqh subject is integrated with fardhu kifayah and Hajj rituals which are routinely carried out as an annual program.

Meanwhile, the innovation of learning supervision at Madrasah Aliyah Negeri 2 Model Medan is carried out based on management supervision from superiors to subordinates, starting from the deputy head of the madrasah and then down to the subject teachers. Then down again, if the problem is related to internal students in the learning process, then the authority to complete is given to the guidance and counseling teachers. But if it is related to discipline and order issues, there are school security (security) who oversees it. Those are not stop at this point. Supervision of students is carried out and monitored to their respective homes, in this case parents have the authority to supervise students.

Furthermore, learning evaluation innovation in improving the quality of Islamic education at Madrasah Aliyah Negeri 2 Model Medan is carried out by implementing routine and scheduled tests, not only in numbers, but also in the form of evaluating students' religious practice in their respective environments.

\section{REFERENCES}

Alba, Cecep. (2011). "Strategi Peningkatan Mutu Pendidikan di Perguruan Tinggi” Jurnal Sosioteknologi, $10(24)$.

http://journals.itb.ac.id/index.php/sostek/article/view/1080.

Alfiansyah, Muhammad, et.al. (2020). "Kebijakan Internal Madrasah dalam Meningkatkan Mutu Pendidikan di MI Nurul Ummah Kotagede Yogyakarta" MAGISTRA: Media Pengembangan Ilmu Pendidikan Dasar dan Keislaman, 11(1), $52-67$.

https://publikasiilmiah.unwahas.ac.id/index.php/MAGISTRA/article/view/3460. 
Anam, Saeful. (2016). "Tinjauan Filosofis tentang Pendidikan: Analisa Terhadap Pendidik dalam Pendidikan Islam” Miyah: Jurnal Studi Islam, 12(1). http://ejournal.inkafa.ac.id/index.php/miyah/article/view/26.

Arikunto, Suharsimi \& Cepi Safruddin Abdul Jabar. (2014). Evaluasi Program Pendidikan: Pedoman Teoritis Praktis Bagi Mahasiswa dan Praktisi Pendidikan. Jakarta: Bumi Aksara.

Ardhi, Mohammad Imam. (2015). "Evaluasi Manajemen Penerimaan Peserta Didik Baru Sistem Real Time Online Dinas Pendidikan Kota Yogyakarta” Jurnal Penelitian Ilmu Pendidikan, $8(1)$, 80-94.

file://C:/Windows/system32/config/systemprofile/Downloads/4930-12364-1SM.pdf.

Asmara, Yeni \& Dina Sri Nindianti. (2019). "Urgensi Manajemen Kelas untuk Mencapai Tujuan Pembelajaran” Sindang: Jurnal Pendidikan Sejarah dan Kajian Sejarah, 1(1), 12-24. https://www.ojs.stkippgrilubuklinggau.ac.id/index.php/JS/article/view/192.

Asmuni. (2015). “Inovasi Manajemen Pembelajaran Sejarah”. Jurnal Manajer Pendidikan $9(4)$, $1-$ 16.https://ejournal.unib.ac.id/index.php/manajerpendidikan/article/download/116 $\underline{2 / 970}$

Assingkily, Muhammad Shaleh \& Mesiono. (2019). "Karakteristik Kepemimpinan Transformasional di Madrasah Ibtidaiyah (MI) serta Relevansinya dengan Visi Pendidikan Abad 21” Manageria: Jurnal Manajemen Pendidikan Islam, 4(1), 147168.

http://ejournal.uinsuka.ac.id/tarbiyah/index.php/manageria/article/view/2475.

Bryson, Jhon M. (2008). Perencanaan Strategis: Bagi Organisasi Sosial, Terj. M. Miftahuddin. Yogyakarta: Pustaka Pelajar.

Direktorat Pendidikan Madrasah. (2014). Madrasah Indonesia; Madrasah Lebih Baik. Jakarta: Direktorat Pendidikan Madrasah, Direktorat Jenderal Pendidikan Islam Kementerian Agama RI.

Dolong, M. Jufri. (2016). "Sudut Pandang Perencanaan dalam Pengembangan Pembelajaran” Jurnal Inspiratif Pendidikan, https://doi.org/10.24252/ip.v5i1.3213. 
Fadhli, Muhammad. (2017). “Manajemen Peningkatan Mutu Pendidikan” Tadbir: Jurnal Studi Manajemen Pendidikan, 1(2). http://journal.iaincurup.ac.id/index.php/JSMPI/article/view/295/o.

Fattah, Nanang. (2001). Landasan Manajemen Pendidikan. Bandung: PT. Remaja Rosdakarya.

Haningsih, Sri. (2008). "Peran Strategis Pesantren, Madrasah dan Sekolah Islam di Indonesia" el-Tarbawi, 1(1). https://doi.org/10.20885/tarbawi.vol1.iss1.art3.

Kuntoro, Alfian Tri. (2019). “Manajemen Mutu Pendidikan Islam” Jurnal Kependidikan, 7(1), 84-97. https://doi.org/10.24090/jk.v7i1.2928.

Kurniawan, Saeful. (2017). "Pengembangan Manajemen Mutu Pendidikan Islam di Madrasah” Al-Tanzim: Jurnal Manajemen Pendidikan Islam, 1(2). https://doi.org/10.33650/al-tanzim.v1i2.111.

Mubarak, Faisal. (2015). "Faktor dan Indikator Mutu Pendidikan Islam” Management of Education, 1(1). http://jurnal.uin-antasari.ac.id/index.php/moe/article/view/342.

Muchsin, Bashori \& Abdul Wahid. (2009). Pendidikan Islam Kontemporer. Bandung: Refika Aditama.

Mutrofin. (2010). Evaluasi Program: Teks Pilihan Untuk Pemula. Yogyakarta: Lakesbang Pressindo.

Napitupulu, Dedi Sahputra. (2018). "Inovasi Sistem Pendidikan Pondok Pesantren: Studi Pada Pondok Pesantren Ar-Raudhatul Hasanah”. Jurnal Al-Fatih 1(2), 267-283. http://jurnal.stit-al-ittihadiyahlabura.ac.id/index.php/alfatih/article/view/14.

Nugroho, Muhammad Aji. (2016). "Urgensi dan Signifikansi Pendidikan Islam Multikultural Terhadap Kompleksitas Keberagamaan di Indonesia” Attarbiyah: Journal of Islamic Culture and Education, 1(2), 179-210. https://doi.org/10.18326/attarbiyah.v1i2.179-210.

Nurcholis. (2003). Manajemen Berbasis Sekolah, Teori, Model dan Aplikasi, Jakarta: PT. Gramedia Widiasarana Indonesia.

Pidarta, Made. (2009). Supervisi Pendidikan Kontekstual. Jakarta: Rineka Cipta.

Priatmoko, Sigit. (2018). "Memperkuat Eksistensi Pendidikan Islam di Era 4.o" Ta'lim: $\begin{array}{llll}\text { Jurnal Studi } \quad \text { Pendidikan } & \text { 1(2), }\end{array}$ https://doi.org/10.29062/ta'lim.v1i2.948.

Purwanto \& Suparman. (1999). Evaluasi Program Diklat. Jakarta: STIA-LAN Press. 
Rahim, Abdan. (2014). "Peran Madrasah Sebagai Pendidikan Islam Masa Kini (Studi Tradisi dan Perubahan)" At-Ta'dib: Journal of Pesantren Education, 9(2). http://dx.doi.org/10.21111/at-tadib.vgi2.312.

Ramdhani, Muhammad Ali. (2014). "Lingkungan Pendidikan dalam Implementasi Pendidikan Karakter" Jurnal Pendidikan Uniga, 8(1). http://journal.uniga.ac.id/index.php/JP/article/view/69.

Rochmawati, Ida. (2012). "Optimalisasi Peran Madrasah dalam Pengembangan Sistem Nilai Masyarakat” Pedagogia: Jurnal Pendidikan, 1(2). https://doi.org/10.21070/pedagogia.v1i2.39.

Rohiat. (2009). Manajemen Sekolah Teori Dasar dan Praktek. Bandung: PT. Refika Aditama.

Rusdiana. (2015). Kebijakan Pendidikan. Bandung: Pustaka Setia.

Sa’ud, Udin Seafuddin. (2011). Inovasi Pendidikan. Bandung: Alfabeta.

Saefuddin, Udin \& Abidin Syamsuddin. (2007). Perencanaan Pendidikan: Suatu Pendekatan Komprehensif. Bandung: Remaja Rosdakarya.

Santoso, Anton Budi \& Shinta Oktafien. (2018). "Peningkatan Prestasi Belajar Mahasiswa dengan Menciptakan Lingkungan Belajar yang Kondusif” Jurnal Muara: Ilmu Sosial, Humaniora dan Seni, http://dx.doi.org/10.24912/jmishumsen.v2i1.1755.

Sarbini \& Neneng Lina. (2011). Perencanaan Pendidikan. Bandung: Pustaka Setia. Sujoko, Edi. (2017). "Strategi Peningkatan Mutu Sekolah Berdasarkan Analisis SWOT di Sekolah Menengah Pertama” Kelola: Jurnal Manajemen Pendidikan, 4(1), 83-96. https://doi.org/10.24246/j.jk.2017.v4.i1.p83-96.

Sulaeman, Mubaidi. (2018). "Urgensi Manajemen Peningkatan Mutu Berbasis Sekolah di Lembaga Pendidikan Islam” Realita: Jurnal Penelitian dan Kebudayaan Islam, 16(1). https://doi.org/10.30762/realita.v16i1.674.

Suryapermana, Nana. (2016). "Urgensi Manajemen Pembelajaran" Tarbawi: Jurnal Keilmuan Manajemen Pendidikan, 2(1), 39-52. https://www.neliti.com/publications/256451/urgensi-manajemen-pembelajaran. Syafaruddin. (2012). Inovasi Pendidikan: Suatu Analisis Terhadap Kebijakan Baru Pendidikan. Medan: Perdana Publishing.

Syafaruddin. (2017). Manajemen Organisasi Pendidikan: Perspektif Sains dan Islam. Medan: Perdana Publishing. 
Syafaruddin, et.al. (2020). "Manajemen Pembelajaran Pendidikan Agama Islam di SDIT Bunayya Pandan Kabupaten Tapanuli Tengah" Auladuna: Jurnal Pendidikan Dasar Islam, 7(1), 32-45. http://repository.uinsu.ac.id/id/eprint/8966.

Syafaruddin \& Erawadi (ed.). (2020). Manajemen dan Kepemimpinan Pendidikan Islam. Medan: Perdana Publishing.

Syaifudin, Muhammad. (2016). "Manajemen Lingkungan Pendidikan: Sebuah Ikhtiar dalam Menciptakan Iklim Pembelajaran yang Kondusif” al-Ihda': Jurnal Pendidikan dan Pemikiran, 11(2), 1-14. https://journal.stainurulfalah.ac.id/index.php/alihda/article/view/26.

Uno, Hamzah B. (2011). Perencanaan Pembelajaran. Jakarta: Bumi Aksara. 